\title{
Heavy metals in benthic organisms from Todos os Santos Bay, Brazil
}

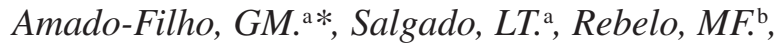 \\ Rezende, CE. ${ }^{\mathrm{c}}$, Karez, $C S .{ }^{\mathrm{d}}$, and Pfeiffer, $W C{ }^{\mathrm{b}}{ }^{\mathrm{r}}$ \\ aPrograma Zona Costeira, Instituto de Pesquisas Jardim Botânico do Rio de Janeiro, \\ Rua Pacheco Leão, 915, CEP 22460-030, Rio de Janeiro, RJ, Brazil \\ 'Laboratório de Radioisótopos, Instituto de Biofísica Carlos Chagas Filho, Universidade Federal do Rio de Janeiro, \\ CEP 22949-900, Rio de Janeiro, RJ, Brazil \\ 'Laboratório de Ciências Ambientais, Centro de Biociências e Biotecnologia, Universidade Estadual do Norte Fluminense, \\ Av. Alberto Lamego 2000, CEP 28023-602, Campos dos Goytacazes, RJ, Brazil

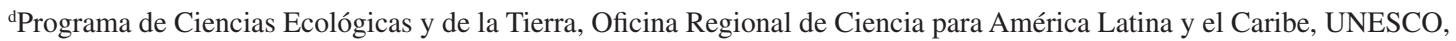 \\ Calle Luis Piera 1992, 2. Piso, 11000 Montevideo, Uruguay \\ *e-mail: gfilho@jbrj.gov.br \\ Received April 10, 2006 - Accepted July 17, 2006 - Distributed February 29, 2008
}

(With 1 figure)

\begin{abstract}
The marine ecosystems of Todos os Santos Bay (TSB, The State of Bahia, Brazil) have been impacted by the presence on its coast of a large metropolitan area as well as of chemical and petrochemical activities. Despite its ecological importance, there is a lack of scientific information concerning metal contamination in TSB marine biota. Thus, we analyzed concentrations of metals in four species of marine benthic organisms (two seaweeds, Padina gymnospora and Sargassum sp. one seagrass, Halodule wrightii and one oyster, Crassostrea rhizophorae) in three sites from the TSB region that have been most affected by industrial activities. The concentrations of $\mathrm{Al}, \mathrm{Cd}, \mathrm{Cr}, \mathrm{Cu}, \mathrm{Fe}, \mathrm{Mn}, \mathrm{Ni}, \mathrm{Pb}$ and $\mathrm{Zn}$ were determined by Atomic Absorption Spectrophometry. The obtained data indicates that cadmium and copper in seaweeds, oysters and seagrass, as well as $\mathrm{Ni}$ concentrations in oysters, were in range of contaminated coastal areas. Cadmium and copper are available to organisms through suspended particles, dissolved fraction of water column and bottom sediment interstitial water. As oysters and other mollusks are used as food sources by the local population, the metal levels found in oysters in TSB may constitute a health risk for this population. Our results suggest implanting a heavy metals biomonitoring program in the TSB marine ecosystems.
\end{abstract}

Keywords: seaweed, seagrass, oyster, bioaccumulation, Todos os Santos Bay.

\section{Metais pesados em organismos bentônicos da Baía de Todos os Santos, Brasil}

\begin{abstract}
Resumo
A Baía de Todos os Santos (TSB, Estado da Bahia, Brasil), vem sendo impactada pela presença, em seu entorno, de uma extensa área metropolitana e por atividades químicas e petroquímicas. Apesar de sua importância ecológica, existe pouca informação sobre a contaminação da biota marinha da TSB por metais pesados. Neste contexto, foram analisadas as concentrações de metais em quatro espécies de organismos bentônicos: duas algas, Padina gymnospora e Sargassum sp.; uma grama marinha, Halodule wrightii; e uma ostra, Crassostrea rhizophorae, em três locais das regiões da TSB mais afetadas pelas atividades industriais. As concentrações de $\mathrm{Al}, \mathrm{Cd}, \mathrm{Cr}, \mathrm{Cu}, \mathrm{Fe}, \mathrm{Mn}, \mathrm{Ni}, \mathrm{Pb}$ and $\mathrm{Zn}$ foram determinadas por espectrofotometria de absorção atômica. Os resultados obtidos indicaram que o cádmio e o cobre em algas, gramas marinhas e ostras, assim como o níquel em ostras estão, em concentrações de áreas contaminadas. Pelos resultados obtidos o cádmio e o cobre estão biodisponíveis a partir das partículas de sedimento em suspensão, fração dissolvida da coluna da água e da água intersticial do sedimento de fundo. Como ostras e outros moluscos são utilizados como fonte de alimento pelas populações locais, as concentrações de metais encontradas nas ostras da TSB podem constituir risco para as populações humanas locais. Os resultados obtidos sugerem a necessidade de implementação de um programa de monitoramento das concentrações de metais pesados em organismos dos ecossistemas marinhos da TSB.
\end{abstract}

Palavras-chave: macroalgas, gramas marinhas, ostras, bioacumulação, Baía de Todos os Santos. 


\section{Introduction}

In contaminated environments, more important than the total load of contaminants, is the bioavailability. According to Phillips and Rainbow (1993), bioavailability can only be measured appropriately by what is found in the tissues of a target organism. Moreover, despite the importance of the chemical species of the contaminant or the abiotic conditions of the environment, bioaccumulation is a biological property and relates directly to the target organism (Beeby, 2001). Thus, it is imperative to use several organisms to evaluate environmental contamination, assessing different uptake capabilities of diverse chemical species and reservoirs.

In marine coastal zones, seagrasses and seaweeds are more exposed to the dissolved fraction of contaminants, and bivalve mollusks to the suspended particles (Rainbow, 1995). For tropical Western Atlantic coastal areas previous studies have shown three benthic organisms as good bioaccumulators of metals: the oyster Crassostrea rhizophorae (Guilding, 1828) exhibits high filtration rates of suspended particles and a high metal bioaccumulation capability (Lima et al., 1986; WallnerKersanach et al., 2000; Rebelo et al., 2003), the brown seaweeds, specially Padina gymnospora (Kuetzing) Sonder, 1871 exhibit high capability of accumulating metals from the dissolved fraction of water column (Amado Filho et al., 1999) and the seagrass Halodule wrightii Ascherson, 1868, which is an important contributor to primary production (Klumpp and Van der Valk, 1984), take up metals from both water, through leaf surfaces, and from sediment and interstitial water, by way of their roots (Pulich, 1980; Amado Filho et al., 2004).

Todos os Santos Bay - TSB $\left(13^{\circ} \mathrm{S}\right.$ and $\left.38^{\circ} \mathrm{W}\right)$ is the largest tropical bay in Brazil with an area of about $1,000 \mathrm{~km}^{2}$ (Figure 1) situated in the state of Bahia (BA). This bay is impacted by the presence of a large metropolitan area (the city of Salvador with 2,600,000 habitants) and industrial activity that includes chemical and petrochemical plants as well as an oil refinery and harbor activities located in the North and Northeastern area of the bay. It also receives discharges from Subae River (Figure 1), which drains an industrial area containing a lead smelter plant, a paper mill and alcohol distilleries. Water circulation is mainly controlled by tide (Lessa et al., 2001). TBS is also an important center of tourism and shell-fishing activities that take place throughout the whole bay. The most important ecosystems are the mangroves situated in the northern part of the bay. There are also reefs in several regions of the bay. Although it's considered ecologically important, there is little data available concerning metal contamination in organisms from TSB. The mollusks Anomalocardia brasiliana (Gmelin, 1791), Brachidontes exustus (Linnaeus, 1758) and Crassostrea rhizophorae were analyzed for their metal content in TSB (Tavares, 1983, Wallner-Kersanach et al., 1994; 2000) and it was shown that differences between TSB area and control sites were detected only for C. rhizophorae.

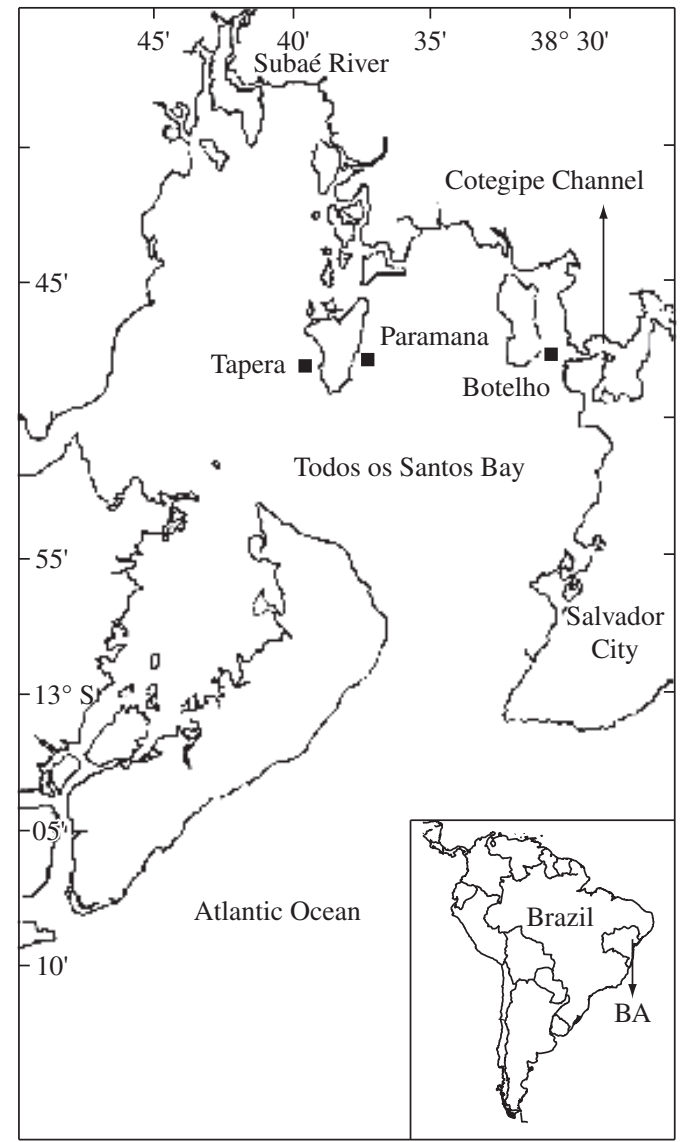

Figure 1. Location of the three collection sites studied (Tapera, Paramana and Botelho) at Todos os Santos Bay, state of Bahia (BA), Brazil. The Cotegipe Channel connects the Aratu Bay to TSB.

Our aim was to assess the heavy metals contamination in the north and northeastern areas of TSB these being the main areas affected by industrial activities. This was done by analysis of metal concentrations in marine benthic organisms: Crassostrea rhizophorae which is a typical sentinel organism (Lima et al., 1986; Wallner-Kersanach et al., 2000; Rebelo et al., 2003) abundant in the mangroves and reefs along the coast, the seagrass Halodule wrightii, which forms extensive beds on the shallow sea bottom (Amado Filho et al., 2004) and Padina gymnospora and Sargassum sp., two abundant seaweed species in Brazilian tropical areas (Karez et al., 1994a; Amado Filho et al. 1999).

\section{Material and Methods}

Organism samples were collected in 3 sites, Botelho, Paramana and Tapera located near industrial areas in the north and the northeastern regions of the Bay (Figure 1). Oyster samples were analyzed only for Botelho and Tapera because populations of this species were not found in Paramana. Samples were collected at the end of 
rainy season in August of 2000. In order to verify a seasonal effect in organism metal concentrations, samples of $C$. rhizophorae and $P$. gymnospora were re-collected in Botelho at the end of the dry season in February of 2001.

Macrophyte Halodule wrightii samples were collected at $2 \mathrm{~m}$ depth, washed and cleaned in seawater accordingly to Amado Filho et al. (2004). Roots, rhizomes and leaves were separated manually. About $3 \mathrm{~g}$ (wet weight) of each plant compartment were washed in seawater and in distilled water and dried at $60{ }^{\circ} \mathrm{C}$ to constant weight. The seaweeds Padina gymnospora and Sargassum sp. were cleaned of epiphytes, washed in seawater, then in distilled water, dried at $60{ }^{\circ} \mathrm{C}$ to constant weight (at least $1 \mathrm{~g}$ ) and then homogenized in porcelain mortar. Around 20 specimens of Crassostrea rhizophorae with similar shell lengths $(3.5 \mathrm{~cm}$ ) and at the same tidal height (low tide) were collected at each station. Soft tissues were removed from the shells and entirely homogenized and dried at $60{ }^{\circ} \mathrm{C}$ to constant weighed and ashed (48 hours at $400{ }^{\circ} \mathrm{C}$ ). The samples were digested accordingly Lacerda et al. (1987) with concentrated $\mathrm{HNO}_{3}$ (Merck, $65 \%$ ) and $\mathrm{HCl}$ (Merck, 37\%) until complete dissolution of the organic tissues. The resulting solution was evaporated and re-dissolved in $0.1 \mathrm{~N} \mathrm{HCl}$.

The concentrations of $\mathrm{Al}, \mathrm{Cd}, \mathrm{Cr}, \mathrm{Cu}, \mathrm{Fe}, \mathrm{Mn}, \mathrm{Ni}$, $\mathrm{Pb}$ and $\mathrm{Zn}$ were determined by Atomic Absorption Spectrophometry (Varian AA-1475) in triplicate samples and the results expressed in $\mu \mathrm{g} \cdot \mathrm{g}^{-1}$ (dry weight). Standard samples from IAEA-140 (Sea plant homogenate, Fucus) and NIST 296 (Mussel) were analyzed and retrieval corresponded to a minimal of $90 \%$ of the reference values.

One-Way Analysis of Variance (ANOVA) was used to compare metal concentrations between parts of Halodule wrightii and among sampling sites. Differences were considered significant when $\mathrm{p}<0.05$ (STATISCA 4.2). Comparisons between obtained data of metal concentrations of TSB organisms and previous published works were done taking in account uniformity in body size, stage of the life cycle, and season of the year.

\section{Results and Discussion}

Average metal concentrations in biological samples are presented in Table 1. Among the organisms sampled in TSB, C. rhizophorae exhibited the highest concentrations for $\mathrm{Cu}\left(526.1 \pm 153.8 \mu \mathrm{g} . \mathrm{g}^{-1}\right), \mathrm{Cd}(8.29 \pm$ $\left.2.43 \mu \mathrm{g} \cdot \mathrm{g}^{-1}\right)$, Ni $\left(1990.9 \pm 91.4 \mu \mathrm{g} \cdot \mathrm{g}^{-1}\right)$ and $\mathrm{Zn}(4733 \pm$ $\left.1291 \mu \mathrm{g} . \mathrm{g}^{-1}\right)$; while $H$. wrightii exhibited the highest concentrations for $\mathrm{Cr}\left(12.2 \pm 4.9 \mu \mathrm{g} \cdot \mathrm{g}^{-1}\right)$, Fe (5664 $\left.\pm 460 \mu \mathrm{g} \cdot \mathrm{g}^{-1}\right), \mathrm{Mn}\left(803.5 \pm 47.8 \mu \mathrm{g} \cdot \mathrm{g}^{-1}\right)$ and $\mathrm{Pb}(13.6 \pm$ $\left.2.0 \mu \mathrm{g} . \mathrm{g}^{-1}\right)$; and P. gymnospora exhibited significantly higher values for $\mathrm{Al}\left(4412 \pm 133 \mu \mathrm{g} \cdot \mathrm{g}^{-1}\right)$.

The concentrations for the nine metals analyzed in $H$. wrightii population from TSB exhibited differences among plant compartments (roots, rhizomes and shoots) and sampling sites (ANOVA, $\mathrm{p}<0.05$ ). In relation to plant compartments, considerably higher concentrations were observed in the roots for eight metals (except for
$\mathrm{Mn})$ when compared to the rhizomes. Concentrations were also notably higher in roots for six metals (except $\mathrm{Cd}, \mathrm{Cu}$ and $\mathrm{Pb}$ ) when compared to shoots. Concentrations were significantly higher in the rhizomes compared to shoots for $\mathrm{Cr}, \mathrm{Fe}, \mathrm{Mn}$ and $\mathrm{Pb}$.

The observed trend of higher metal concentrations in roots than rhizomes and shoots, suggests that $H$. wrightii roots are the main compartment for metal accumulation, reflecting the metal concentration and availability in the sediment pore waters. On the other hand, Mn which presented an elevated concentration in the shoots, has been noted in other seagrass species as a metal that tends to be accumulated in a higher degree in shoots, as was pointed out by Malea (1994), Sanchiz et al. (1999) and Prange and Dennison (2000).

In the comparison of the sample sites, it was found that samples from Botelho exhibited significantly higher concentrations than Paramana or Tapera for Al (root), $\mathrm{Cd}$ (root), $\mathrm{Cu}$ (root, rhizome and shoot), Fe (root, rhizome and shoot), Mn (rhizome and shoot) and $\mathrm{Zn}$ (root and shoot); Tapera presents higher concentrations than Paramana of Al (root) and Mn (shoots). No differences were detected in $\mathrm{Cr}$, $\mathrm{Ni}$ and $\mathrm{Pb}$ concentrations among the three sample sites.

In relation to the metal concentrations in seaweeds, the same trend observed in the seagrass of highest metal concentrations in Botelho was seen. P. gymnospora presented significantly higher concentrations of $\mathrm{Al}, \mathrm{Cu}, \mathrm{Fe}$, $\mathrm{Mn}$ and $\mathrm{Zn}$ in Botelho and $\mathrm{Cd}$ in Tapera. Sargassum spp. presented higher concentrations of $\mathrm{Cr}$ in Botelho, $\mathrm{Cd}$ in Tapera and $\mathrm{Cu}$ and $\mathrm{Mn}$ in Paramana.

In oyster samples, differences between sites were seen in the following metals, $\mathrm{Cd}, \mathrm{Cr}, \mathrm{Cu}, \mathrm{Fe}, \mathrm{Ni}, \mathrm{Zn}$. Higher concentrations of $\mathrm{Cr}, \mathrm{Cu}, \mathrm{Ni}$ and $\mathrm{Zn}$ were observed in Botelho and higher concentrations of $\mathrm{Cd}$ and Fe were observed in Tapera.

The observed trend of higher metal concentrations in samples from Botelho can be related to the localization of this site in front of Cotegipe Channel. This channel connected the Aratu Bay (Figure 1) to TSB. Most industries are situated in the northern part of the Aratu Bay. Direct anthropogenic contributions from the Cotegipe Channel originate from an ore terminal, harbor activities of naval vessels and offshore oil rig repairs, and transport of organic products (Wallner-Kersanach et al., 2000).

Even though there was a general trend of higher metal concentration in both $P$. gymnospora and $C$. rhizophorae observed in the rainy season (2000) when compared to the dry season (2001) (Table 1), no significant difference ( $p<0.05)$ was detected between both seasons, and the levels of all analyzed metals were maintained in the same range. The available data about salinity of TSB indicates that the main portion of the Bay is dominated by typical marine conditions (range of 33.0 and 36.7 PSU) that don't change seasonally (Wolgemuth et al., 1981; Lessa et al., 2001). In this way, the levels of metal accumulated by benthic organisms of the studied sites should be more related to the load of metals to the Bay system by the 


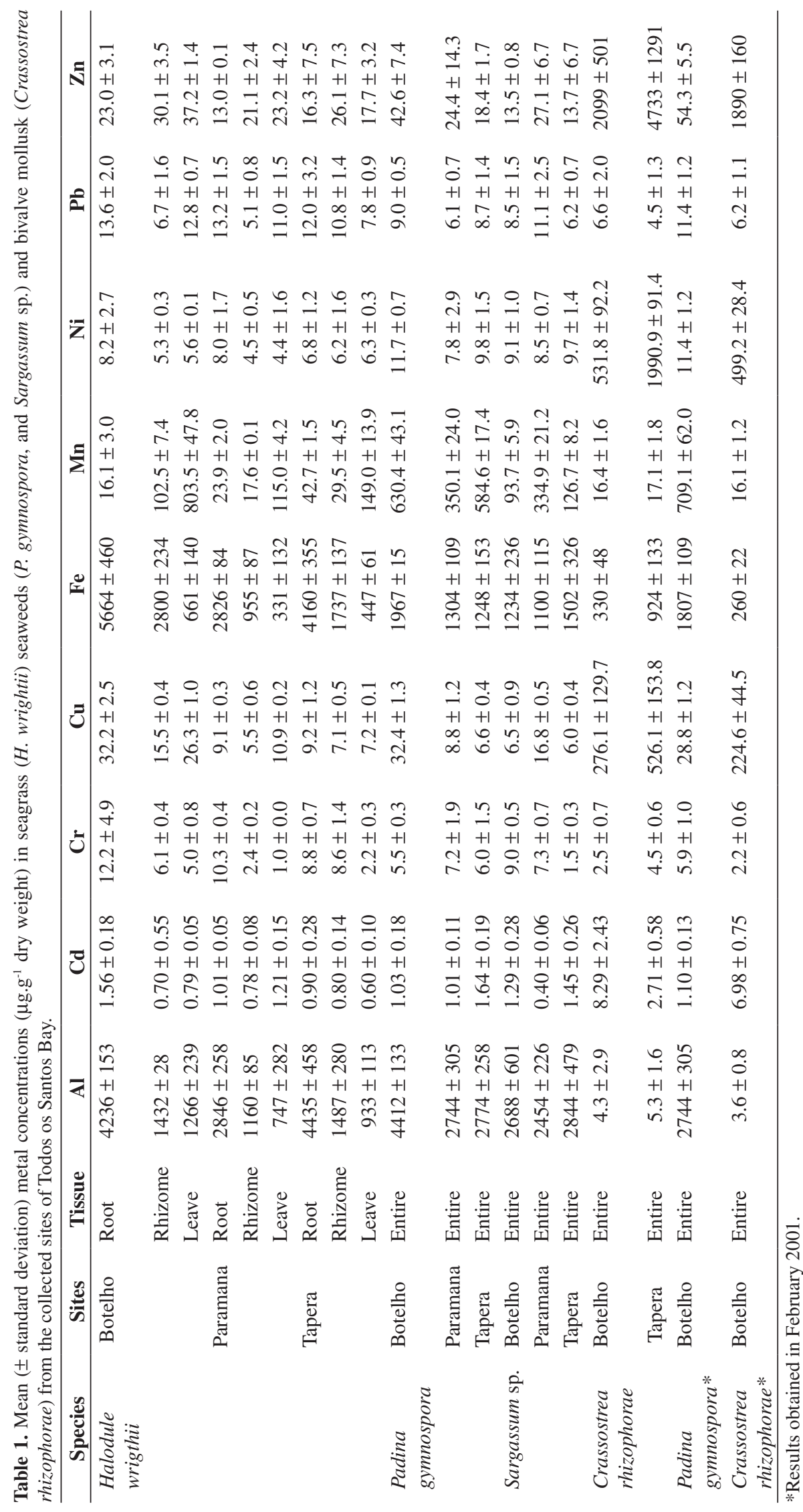


anthropogenic inputs than natural seasonal changes of abiotic parameters.

A comparison between the obtained data with other results of contaminated Brazilian coastal areas by using the same studied species shows that the metals $\mathrm{Cd}$, $\mathrm{Cu}$ and $\mathrm{Ni}$ from TSB were in the similar range of concentrations (Amado Filho et al., 1999; Rebelo et al., 2003). The higher Cd concentrations of $1.56 \mu \mathrm{g} . \mathrm{g}^{-1}$ in seagrass, $1.64 \mu \mathrm{g} . \mathrm{g}^{-1}$ in seaweed and $8.29 \mu \mathrm{g} . \mathrm{g}^{-1}$ in oyster are similar to that concentrations found in Sepetiba Bay (H. wrightii $=0.4-1.5 \mu \mathrm{g} \cdot \mathrm{g}^{-1}$, Amado Filho et al., 2004; P. gymnospora 1.0-2.7 $\mu \mathrm{g} . \mathrm{g}^{-1}$, Amado Filho et al., 1999; C. rhizophorae $=1.3-29.8 \mu \mathrm{g}^{-\mathrm{g}^{-1}}$, Rebelo et al., 2003), which have been studied due to the impact of a $\mathrm{Cd}$ and $\mathrm{Zn}$ smelting plant. Cadmium concentrations found in TSB samples are higher than that found in non contaminated Brazilian coastal areas $(H$. wrightii $=$ 0.2-0.3 $\mu \mathrm{g} . \mathrm{g}^{-1}$, Amado Filho et al., 2004; P. gymnospora $=$ 0.30-0.42 $\mu \mathrm{g} . \mathrm{g}^{-1}$, Karez et al., 1994a; C. rhizophorae $=$ 0.8-2.3 $\mu \mathrm{g} . \mathrm{g}^{-1}$, Rebelo et al., 2003). The $\mathrm{Cu}$ concentrations of $32.2 \mu \mathrm{g} . \mathrm{g}^{-1}$ in seagrass, $32.4 \mu \mathrm{g} . \mathrm{g}^{-1}$ in seaweed and $526.1 \mu \mathrm{g} . \mathrm{g}^{-1}$ in oysters were higher than those observed in $\mathrm{Cu}$ contaminated areas, like Guanabara Bay (P. gymnospora $=13.6 \pm 0.9 \mu \mathrm{g} \cdot \mathrm{g}^{-1}$, Karez et al., 1994b; C. rhizophorae $=148 \mu \mathrm{g} \cdot \mathrm{g}^{-1}$, Carvalho and Lacerda, 1992) and the Potengi River Estuary (C. rhizophorae $=$ $234 \pm 55 \mu \mathrm{g} \cdot \mathrm{g}^{-1}$, Silva et al., 2001) and other less contaminated areas $\left(H\right.$. wrightii $=4.0-14.1 \mu \mathrm{g} . \mathrm{g}^{-1}$, Amado Filho et al., 2004). Among the three considered organisms only the oysters exhibited higher $\mathrm{Ni}$ concentrations. In relation to other Brazilian coastal areas, Ni concentrations in

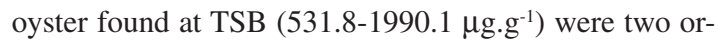
der of magnitude higher than previously reported values (15-20 $\mu \mathrm{g} . \mathrm{g}^{-1}$, Carvalho et al., 1991 and Pfeiffer et al., 1985). Wallner-Kersanach et al. (2000) who carried out transplant experiments with $C$. rhizophorae populations of TSB during the year of 1991 , analyzed $\mathrm{Cd}, \mathrm{Cu}, \mathrm{Pb}$ and $\mathrm{Zn}$ in oysters from Cotegipe Channel (Figure 1). Comparison of data between 1991 and 2000 showed similar concentrations of $\mathrm{Cu}$ and $\mathrm{Zn}$ and an increase of $\mathrm{Cd}$ and $\mathrm{Pb}$ concentrations in 2000 .

When wet weight is considered, the concentrations of $\mathrm{Cu}$ and $\mathrm{Ni}$ in oysters from TSB exceeded the limits recommended for human consumption according to the Brazilian Health Agency $\left(\mathrm{Cu}\right.$ and $\mathrm{Ni}<2.0 \mu \mathrm{g}$. $\mathrm{g}^{-1}$ wet weight). As oysters and other mollusks are used as food sources by the local population, the contaminated oysters of TSB may constitute a health risk for this population.

In addition to previous results of metal concentrations in oysters (Wallner-Kersanach et al. 2000), the obtained data from TSB indicates that $\mathrm{Cd}$ and $\mathrm{Cu}$ concentrations were in range of contaminated coastal areas. This conclusion is supported by levels of $\mathrm{Cd}$ and $\mathrm{Cu}$ in seaweeds, seagrass and oysters. Cadmium and $\mathrm{Cu}$ are available to organisms through suspended particles, dissolved fraction in the water column and bottom sediment interstitial water. Although the observed result of $\mathrm{Ni}$ in oysters indicates elevated concentration, they were not supported by results in other organisms, suggesting that more evidence is needed to confirm this element as a contaminant in TSB. In summary, our results show the usefulness of analyzing different organisms that can take up metals from different ecosystem compartments and that a heavy metals biomonitoring program has to be implemented in the marine biota of TSB.

Acknowledgments - This study was financially supported by the Brazilian Program PRONEX/MCT and by research grants from the Conselho Nacional de Desenvolvimento Científico e Tecnológico (CNPq-Brazil) to GM Amado Filho (521688/96-5) and CE Rezende (420110/97-6).

\section{References}

AMADO FILHO, GM., FARINA, M., PFEIFFER, WC., KAREZ, CS. and ANDRADE, LR., 1999. Brown algae species as biomonitors of $\mathrm{Zn}$ and $\mathrm{Cd}$ at Sepetiba Bay, Rio de Janeiro, Brazil. Mar. Environ. Res. vol. 48, no. 3, p. 213-224.

AMADO FILHO, GM., CREED, JC., ANDRADE, LR. and PFEIFFER, WC., 2004. Metal accumulation by Halodule wrightii populations. Aquat. Bot., vol. 80, no. 4, p. 241-251.

BEEBY, A., 2001. What do sentinels stand for? Environ. Poll. vol. 112 , no. 2, p. 285-298

CARVALHO, CEV., LACERDA, LD. and GOMES, MP., 1991. Heavy metals contamination of The Marine Bentic Biota of Rio de Janeiro Coast, SE-Brazil. Wat. Air Soil Poll. vol. 57, no. 8, p. 645-653.

CARVALHO, CE. and LACERDA, LD., 1992. Heavy metals in the Guanabara Bay biota: why such low concentrations ? Ciên. Cult. vol. 44, no. 2/3, p. 184-186.

KAREZ, CS., MAGALHÃES, VF., PFEIFFER, WC. and AMADO-FILHO, GM., 1994a. Trace metal accumulation by algae in Sepetiba bay, Brazil. Environ. Poll. vol. 83, no. 3, p. 351-356.

KAREZ, CS., AMADO-FILHO, GM., MOLL, DM. and PFEIFFER, WC., 1994b. Concentrações de metais em algas marinhas bentônicas de três regiões do estado do Rio de Janeiro. An. Acad. Bras. Ci. vol. 66, no. 2, p. 205-211.

KLUMPP, DW. and VAN DER VALK, A., 1984. Nutritional quality of seagrass Posidonia australis and Heterozostera tasmanica: comparison between species and stages of decomposition. Mar. Biol. Lett., vol. 5, no. 2, p. 67-84.

LACERDA, LD., PFEIFFER WC. and FISZMAN, M., 1987. Heavy metal distribution, fate and availability in Sepetiba Bay, SE Brazil. Sc.Tot. Environ. vol. 65, p. 163-173.

LESSA, GC., DOMINGUES, JML, BITTENCOURT, ACSP. and BRICHTA, A., 2001. The tides and tidal circulation of Todos os Santos Bay, Northeast Brasil, a general characterization. An. Acad. Bras. Cienc. vol. 73, no. 2, p. 245-261.

LIMA, NRW., LACERDA, LD., PFEIFFER, WC. and FISZMAN, M., 1986. Temporal and spatial variability in Zn, $\mathrm{Cr}, \mathrm{Cd}$ and $\mathrm{Fe}$ concentrations in oyster tissues (Crassostrea brasiliana, Lamarck 1819) from Sepetiba Bay, Brazil. Environ. Techn. Lett., vol. 7, no. 8, p. 453-460.

MALEA, P., 1994. Seasonal variation and local distribution of metals in the seagrass Halophila stipulacea (Forsk.) Aschers. 
in the Antiryra Gulf. Greece. Environ. Pollut. vol. 85, no. 1, p. 77-85.

PFEIFFER, WC, LACERDA, LD., FISZMAN, M and LIMA, NRW., 1985. Metais pesados no pescado da baía de Sepetiba, estado do Rio de Janeiro. Ciên. Cult. vol. 37, no. 2, p. 197-302.

PHILLIPS, DJH. and RAINBOW, PS., 1993. Biomonitoring of Trace Aquatic Contaminants. Elsevier Applied Science: New York, NY

PRANGE, JA. and DENNISON, WC., 2000. Physiological responses of five seagrass species to trace metals. Mar. Pollut. Bull. vol. 42, no. 7-12, p. 327-336.

PULICH, WM., 1980. Heavy metal accumulation by selected Halodule wrightii Aschers. populations in the Corpus Christi Bay area. Contrib. Mar. Sci. vol. 23(aug), p. 89-100.

RAINBOW, PS., 1995. Biomonitoring of Heavy Metal Availability in the Marine Environment. Mar. Poll. Bull., vol. 31, no. 4-12, p. 183-192.

REBELO, MF., AMARAL, MCR. and PFEIFFER, WC., 2003. High $\mathrm{Zn}$ and $\mathrm{Cd}$ accumulation in the oyster Crassostrea rhizophorae, and its relevance as a sentinel species. Mar. Poll. Bull. vol. 46, no. 10, p. 1341-1358.

SANCHIZ, C., GARCIA-CARRASCOSA, AM. and PASTOR, A., 1999. Bioaccumulation of $\mathrm{Hg}, \mathrm{Cd}, \mathrm{Pb}$, and $\mathrm{Zn}$ in four marine phanerogams and the alga Caulerpa prolifera (Forsskal) Lamouroux from the east coast of Spain. Bot. Mar. vol. 42, no. 2, p. 155-164.

SILVA, CAR., RAINBOW, PS., SMITH, BD. and SANTOS, ZL., 2001. Biomonitoring of trace metal contamination in the Potengi estuary (Natal) Brazil, using the oyster Crassostrea rhizophorae, a local food source. Wat. Res. vol. 35, no. 17, p. $4072-4078$.

TAVARES, TM. and PESO-AGUIAR, MC., 1983. Caracterização Ecológica da Baía de Todos os Santos (BahiaBrasil) sob Impacto de Poluição por Metais Pesados. Atlântica, vol. 5, no. 2, p. 116.

WALLNER-KERSANACH, M., U., LOBO. S. and da SILVA, EM., 1994. Depuration effects on trace metals in Anomalocardia brasiliana (Gmelin, 1791). Bull. Environ. Cont. Toxicol, vol. 52, no. 6 , p. $840-847$.

WALLNER-KERSANACH, M., THEEDE, H., EVERSBERG and U., LOBO. S., 2000. Accumulation and elimination of trace metals in a transplantation experiment with Crassostrea rhizophorae. Arch. Environ. Cont. Toxicol. vol. 38, no. 1, p. 40-45.

WOLGEMUTH, KM., BURNETT, WC. and MOURA, PL., 1981. Oceanography and suspended material in Todos os Santos Bay. Rev. Bras. Geoc. vol. 11, no. 3, p. 172-178. 